\title{
Peer Education Strategy Through the Utilization of Information Technology Media in Effectiveness of New Normal Policies as An Efforts to Control Covid- 19 Pandemic
}

\author{
Sutrisno*, Eko Wahyudi, Anajeng Esri Edhi Mahanani \\ Law Faculty, Universitas Pembangunan Nasional “Veteran' Jawa Timur, Indonesia
}

${ }^{*}$ Corresponding author:

E-mail:

sutrisnohukum88@yahoo.com

\begin{abstract}
2020 is a test year for each country globally. The Covid-19 pandemic is a scourge from various sides/fields of life in society, nation, and state. In Indonesia, the impact of the Covid-19 pandemic has been felt in the health, economy, even social and policy sectors. The pandemic, which started at the end of 2019 until now, still leaves homework for various countries, including Indonesia, to immediately carry out countermeasures effectively and efficiently. The policy that will then be taken sees the condition that is still unstable, then leads to WHO recommendations, namely the application of the new normal, including in Indonesia. The policy New Normal which leads to encouraging the implementation of "normal" social, national, and state life and side by side with Covid-19 while still implementing strict health protocols, will not work optimally if the level of public awareness is not high. People who are not alert and vigilant and lead to apathy about the policies and conditions of Covid-19 will have an even bigger "iceberg" impact. This study aims to disseminate information through a peer education strategy with the help of information technology-based media related to the implementation of the policy New Normal in the response to Covid 19 in Indonesia. This socialization is packed with technological developments and a touch of humanism in society and industrial development 5.0. This research is expected to be a form of the contribution of UPN "Veteran" East Java to the local community, nation, and state. In particular, this is to help make the policy effective New Normal in dealing with the impact of Covid 19 in Indonesia.
\end{abstract}

Keywords: Peer education strategy, technology information, Covid-19

\section{Introduction}

The stability curve of the covid-19 pandemic in Indonesia has not succeeded in stabilizing it, even being put at zero points of the development curve. Various countries have issued their respective policies in terms of dealing with and preventing the more widespread impact of the Covid-19 pandemic. The Covid-19 pandemic has become a scourge from various sides/fields of life in society, nation, and state. In Indonesia, the impact of the Covid-19 pandemic has been felt in the health, economy, even social and policy sectors. The pandemic, which began at the end of 2019 until now, still leaves homework for various countries, including Indonesia, to immediately carry out countermeasures effectively and efficiently.

In the context of tackling and preventing the widespread impact of the Covid-19 pandemic, Indonesia has implemented various policies such as financial assistance, diversion of the use of financial policies, to large-scale social restrictions (PSBB). This PSBB is implemented through cooperation with the regions, as Indonesia is a country that adheres to regional autonomy. The policies, which then vary in practice, and are not uniform, have more or less affected the handling of the Covid-19 pandemic. 
The government then inevitably accepts WHO's recommendation in response to the Covid-19 pandemic problem, namely implementing a new habitual adaptation policy. Recorded on 19 October 2020, 365,240 confirmed covid-19, and 12,617 deaths, with the following graph (Aplikasi Edukasi Kebijakan Adaptasi Kebiasaan Baru):

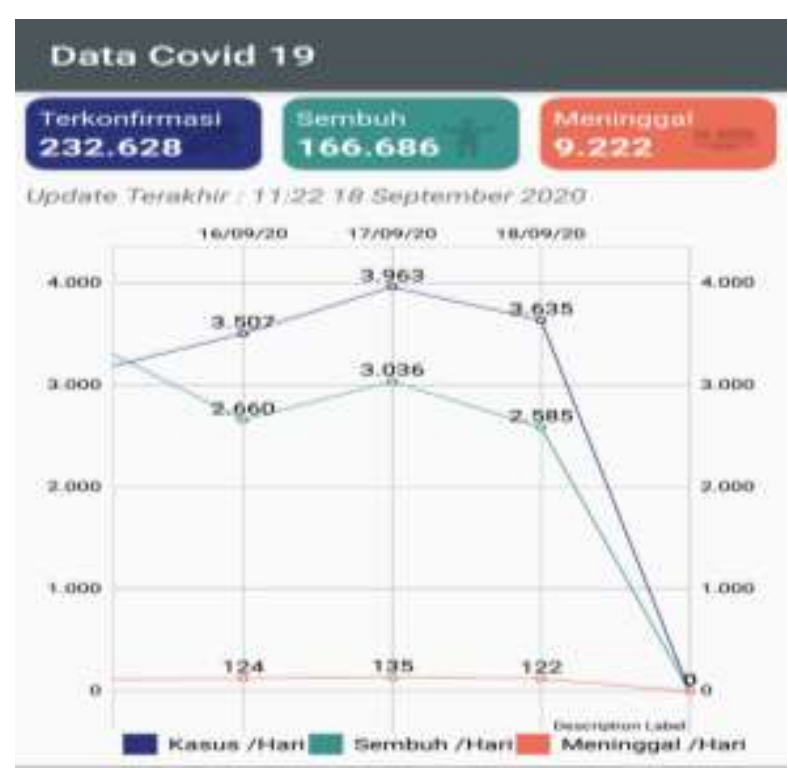

Figure 1. The data Covid-19

A large number of cases of Covid-19 in Indonesia, cannot be separated from the strictness of government policies, and whether the policies of the central government and local governments are not compatible. East Java Province itself is a province that has the second-highest number of Covid-19 cases in Indonesia, after DKI Jakarta.

The New Habit Adaptation Policy, which will be taken as if to "free" community activities during a pandemic that has not ended, will be the fruit of simalakama for the increase in the covid19 pandemic case curve going forward if this policy is not accompanied by strict implementation and control of health protocol.

In other words, the New Habit Adaptation policy which leads to encouraging the implementation of "normal" social, national, and state life and side by side with Covid-19 while still implementing strict health protocols will not work optimally if the level of public awareness is not high. People who are not alert and vigilant and lead to apathy about the policies and conditions of Covid-19 will have an even bigger "iceberg" impact.

The young generation is a golden generation that must be of particular concern in the spread of this Covid-19 case. Apart from the possibility of high mobility of young people during the Covid19 pandemic, the younger generation must also be maintained to support the health of the nation's successors. The role of the young generation in efforts to overcome and prevent the spread of the impact of Covid-19 is needed.

The young generation who are technology literate and have broad mobility links should be able to be used as smart cadres to prevent Covid-19 in Indonesia. This young generation can become a pioneer in providing peer education, which is often referred to as the "peer education strategy".

\section{Material and Methods}

The design of this research is (socio-legal researchsocio-legal research). Therefore, this study is characterized by a sociological study of law. Law is conceptualized as law as what it is (functioning) in society (Wignjosoebroto, 2002). Participant Observation, through field 
observations concerning cases in the field as well as the opinions of participants/respondents in building an ideal covid-19 prevention and control education model concept. By proposing the model Peer Strategy Education and the use of information technology media.

\section{Results and Discussion}

Information technology is a technology used to manage, process, and obtain quality information in real-time, relevant, and accurate which is used by individuals and groups of people for decision making. This information technology uses easy-to-carry electronic devices such as devices and computers or laptops which have supporting features to convey or provide information globally according to the needs and accuracy in the understanding obtained.

The role that can be taken from the development of information technology is that the public is easier to find information and easier in obtaining information such as information about government policies on handling Covid to other supporting regulations. In the development of information technology at this time, most groups of Indonesian society get information widely.

The policy itself is to return to the development of information technology, this development makes it easier for legal experts to exchange opinions online, especially during the pandemic Covid-19, because according to government directives, the community is obliged to implement WFH (Work From Home) or it is called working at home so that the role of information technology very big. This is supported by the implementation of the New Habit Adaptation announced by the government, so that information technology is very influential in this era and has flocked to improve the quality of its information technology.

The role of the development of information technology in the socialization of law during a pandemic like this is very influential because according to research conducted by the Alvara Research Center, it is revealed that internet users jumped quite significantly during the pandemic Covid-19, the data states that public spending on internet needs in 2020 reached 8.1 percent, up from 6.1 percent last year.

So that the research conducted by Alvara Research shows that the Indonesian people are active in carrying out online activities at all levels of society from the general public to civil servants in government. Therefore, the role of information technology development in the socialization of law is very important during a pandemic. In this case, it is also supported by the existence of a fairly low level of public awareness of the pandemic Covid-19, moreover, the information presented in the media is very diverse, thus increasing public indifference to health protocols.

In the development of information technology, it has a positive impact and a negative impact on society, the positive impact that can be taken is that people are not blind to information during a pandemic. so that people can prepare themselves so as not to be infected with the virus. The negative impact also has an impact on society, because the world of information is increasingly open, it is difficult for the public to distinguish clear information from sources and information that is a hoax, if this happens continuously, the level of public indifference to the pandemic will increase.

On May 7, 2020, the Ministry of Communication and Informatics of the Republic of Indonesia (Kominfo RI), Directorate General of Application and Information Technology (Ditjen Aptika) stated that until 5 May 2020 it had found 1,401 cases of hoax information dissemination and being informed in the community, this data will continue to grow until the case covid-19 is over. Minister of Communication and Information, Jonny G, said that hoax and disinformation cases were spread, including on social media platforms Facebook, Twitter, Instagram (http://aptika.kominfo.go.id/2020/05/kominfo-temukan-1-401-sebaran-isu-hoax-terkait-covid-19/). So that in this case, the researcher makes an application innovation that is easily accessible by all levels of society, namely a device application called "New Habits.apk", in this application the researcher provides important information about the development of Covid-19 in Indonesia and emphasizes 
more on policy. - government policies in the form of laws, ministerial regulations, and circulars. So that researchers hope that the public will be well educated by the presence of this application and be able to reduce the level of public indifference to the pandemic Covid-19. The following is an overview of the application that the research team launched:
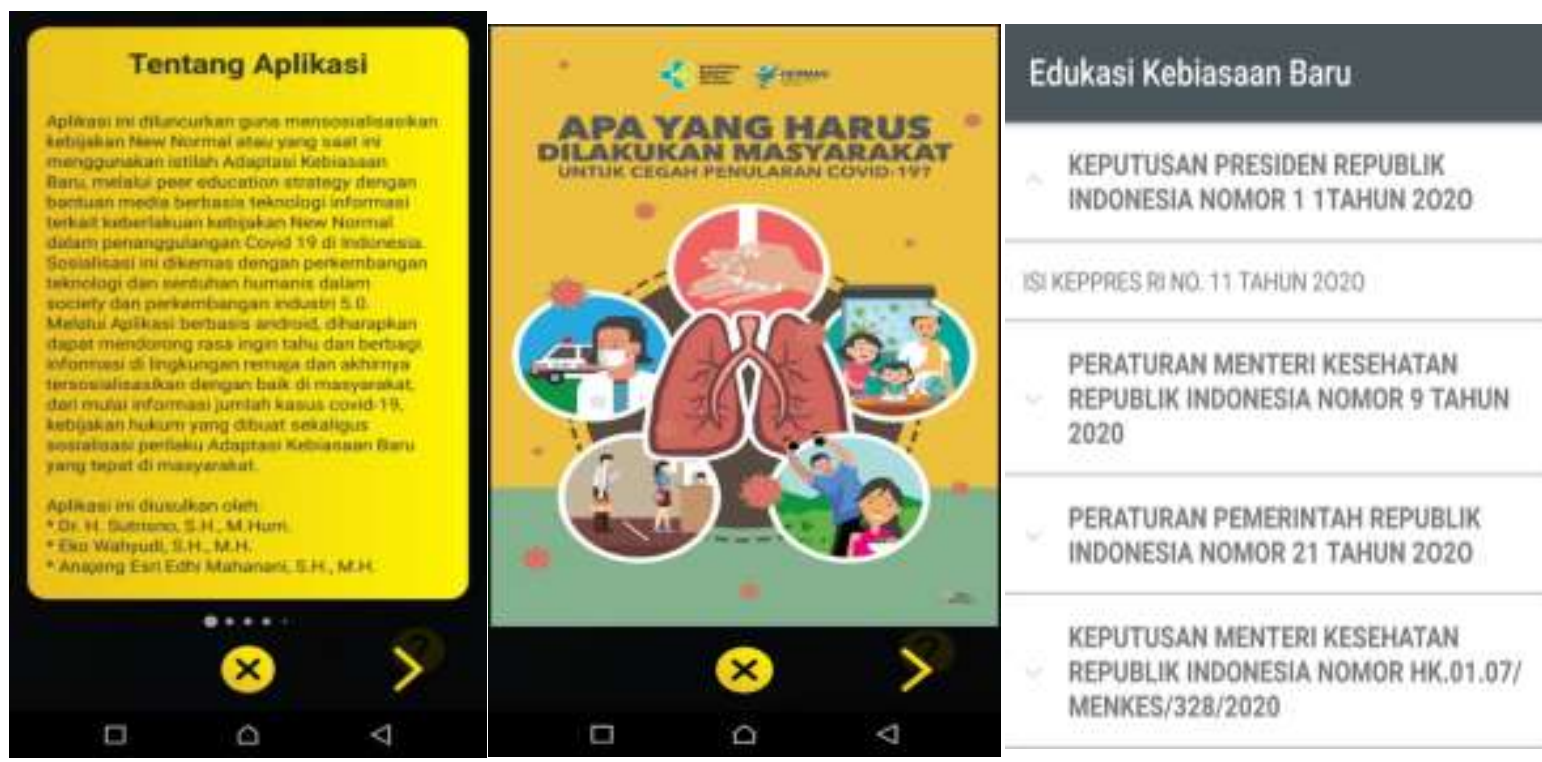

Figure 2. The application that the research ream

\section{Peer education strategy, technology information, Covid-19}

The future of the Indonesian state today is largely determined by the younger generation. Indonesian youth are the future of the Indonesian nation. Therefore, every Indonesian youth is an important factor in the progress of the Indonesian Nation so that young people today are very much needed by the State and are very relied on by the Indonesian people in realizing the ideals of the nation. Youth have a role and function of change, including the life process and law enforcement in Indonesia. The good and bad of a country can be seen from the quality of the youth itself.

The youth generation is the heir of the nation and state. The youth generation must have a strong soul and character to build their nation and country, have a tall personality, a spirit of nationalism, have a competitive spirit, be able to understand the technology and legal knowledge both nationally and globally. So that law enforcement in Indonesia will be more assertive and fair in terms of the law. Youths must also pay attention and realize that the function of youth is as Agents of Change, Moral Force, and Social Control so that these functions can be useful for the Indonesian nation.

"The Founding Father" Indonesia believes in young people that they can provide a direction of movement to become a prosperous and prosperous nation and can make Indonesia proud in foreign countries, the word is still often heard today, namely "Give me 100 parents then I will pull up the mountain. semeru from the roots, give me 10 young men then I will shake the world. So from that sentence, young people are more enthusiastic about investing in each other in various fields, one of which is in law enforcement in Indonesia.

Every Indonesian youth, whether still as a student, college student, or who has completed education are actors who are highly relied on to realize the dream of enlightening the life of our nation in the future. To achieve these goals, our nation has also agreed to establish national independence in the composition of the Republic of Indonesia as a country that is democratic law (DemocratischeRechtsstaat) and as a Democratic State constitutional (ConstitutionalDemocracy) based on Pancasila (Asshidiqie et al., 2009). 
To realize these ideals, of course, there are many challenges, problems, obstacles, obstacles to threats that must be faced. The problems that must be faced are of various styles and dimensions, so these problems must be faced by the Indonesian people. Many problems arise as a legacy of the past, many new problems arise today or in the future, especially in the field of law which is increasingly broad in scope so that in this case young people must have the courage to adapt to the development of existing laws so that justice remains to stand up fairly.

Every citizen has the right and obligation to participate in efforts to defend the state through civic education, compulsory basic military training, service as a soldier in the Indonesian National Army, and service following the profession. Youth in this case can be any part according to ability. This can be done by becoming a major component through military service, reserve components, and supporting components. More specifically, Law Number 40 of 2009 concerning Youth regulates the responsibilities and rights of youth.

This is stated in Article 16:

Youth plays an active role as a moral force, social control, and agents of change in all aspects of national development.

This is the obligation for youth to make it happen following Article 17 paragraph 1 to paragraph 3, besides that in Article 17 paragraph (2) letter c, the role of youth as social control must be realized by generating a critical attitude towards the environment and law enforcement. Quoting from Tan Malaka that "Idealism is the last luxury possessed by youth" in the sentence means that we as young people who still have an idealistic spirit play an important role in the nation because if the reality is hit, the role of youth about idealism will be lost.

It is further explained about the responsibilities and roles of youth as Indonesian citizens in Article 19:
a. Youth is responsible for national development for:
b. Maintain Pancasila as the state ideology;
c. Maintaining the integrity of the Unitary State of the Republic of Indonesia;
d. Strengthening the unity and integrity of the nation;
e. Implementing the constitution, democracy, and upholding the law;
f. Improve intelligence and community welfare;
g. Increase the resilience of national culture; and/or
$\mathrm{h}$. Increase the competitiveness and independence of the nation's economy.

From Article 19 letter d, it is written that the Indonesian youth are obliged to implement the constitution, democracy, and uphold the law. Because youth are the heirs of the nation who will determine the future of the nation itself, it can be concluded that the role of youth or youth plays an important role in law enforcement in Indonesia. Youths with strong souls, the nation will remain intact and will be strong.

Peer Education Strategy, in this case, is peer education, invites youth to participate in socializing the New Habit Adaptation policy. Peer education is based on the assumption that students tend to relate to other people and trust their peers more than someone more experienced or professional such as their parents or teachers (Community health and development at 15 the University of Kansas, 2014). The education provided is more beneficial to be implemented between peer groups so that communication becomes more open. Matters that cannot be discussed with other people, including those that are sensitive, can be discussed openly and can be resolved together so that the results are better. Peer education can be used to change individual behavior to be positive by modifying one's knowledge or behavior, and it can influence change at the group or community level by modifying norms (Hayati, 2009).

\section{Conclusion}

The results of the study can be concluded that: 
1. The Covid-19 pandemic has an impact on various aspects of life, one of which is the legal aspect;

2. Legal policies need to be disseminated to the public so that they can be right on target and people understand and are aware of the law;

3. An interesting socialization model is needed, namely through a peer education strategy.

\section{Acknowledgment}

The author would like to thank UPN “Veteran” Jawa Timur, ISRM 2020’s Comitte

\section{References}

Asshidiqie, J. (2009). Pengantar ilmu hukum tata negara. Jakarta: Raja. Grafindo Persada.

Community Health and Development at 15the University of Kansas, 2014.

Hayati A. W. (2009). Buku saku gizi bayi. Jakarta : EGC Jakarta.

http://aptika.kominfo.go.id/2020/05/kominfo-temukan-1-401-sebaran-isu-hoax-terkait-covid-19/

Pasal 16 Undang-undang Nomor 40 Tahun 2009 tentang Kepemudaan.

Undang-undang Nomor 40 Tahun 2009tentang Kepemudaan (Lembaran Negara Republik Indonesia No. 148, Tambahan Lembaran Negara Republik Indonesia No.5067)

Wignjosoebroto, S. (2002). Hukum paradigma, metode dan dinamika masalahnya, elsam dan huma. Jakarta, 193. 